\title{
Canada gets a marginal grade on childhood injury
}

Published at www.cmaj.ca on Sept. 2I, 2006.

I $\mathrm{n}$ this issue, Birken and coauthors document a substantial decline from I97I to I998 in the rate of unintentional injuries among Canadian children living in urban areas (see page 867). ${ }^{1}$ They also determine that, for these injuries, the disparity in rates between rich and poor children has fortunately not widened. Nevertheless, poor children are still twice as likely as those of affluent families to die of an unintentional injury. The proportion of this stratum that comprises vulnerable groups (e.g., First Nations and refugee children) needs at least to be acknowledged and is worthy of a discussion beyond the scope of this editorial.

Although the disparity in injury-related death rates between rich and poor children may prompt moral indignation, a measure of outrage should be saved for Canada's overall performance in pediatric injury control. UNICEF's second Innocenti Report Card, which focuses on child deaths by type of injury, ranks Canada I8th of 26 OECD nations for deaths from both intentional and unintentional injuries among children I-I4 years of age during I99I-I995. ${ }^{2}$ Not surprisingly, Canada fared worse than the world leaders from the Scandinavian countries; however, it also did worse than Spain, Greece and Australia. Had Canada enjoyed the rate achieved by the leader Sweden, 2665 more children would be alive today.

Birken and coauthors ${ }^{1}$ suggest targeted interventions to narrow the gap in injury-related death rates between rich and poor children. In addition, in a related commentary Howard ${ }^{3}$ calls for, among several measures, greater injury prevention advocacy (see page 899). This latter approach of championing public policy has been taken up with particular success by the Canadian Paediatric Society with the issuance of its first report card on Canadian public policy and child and youth health. ${ }^{4}$ In this report, the society highlights both good and questionable public policy on childhood injuries. It stresses traffic-related issues such as bicycle helmets, booster seats, all-terrain vehicles and graduated licensing. The report establishes benchmarks against which to evaluate one's own jurisdictional rankings and, with future editions, monitor progress. Anomalies and inconsistencies in healthy public policy are underscored in the report, as are opportunities and successes. For example, one province has an excellent graduated licensing program but, because of a lack of regulation, allows for 2-year-old children to legally operate offroad vehicles. Another province scores well on these listed injury control measures but gets a poor score on bicycle helmet legislation. The broad adoption of the best legislation would benefit all Canadian children. Such an approach concentrates on environmental change to secure injury reductions rather than solely relying on programs that focus on the behaviours of the individual or family. In keeping with this broad environmental approach, I suggest that we not only consider targeted interventions for poor children but that we also look at the facet of the social environment that is at the root of the disparity in injury-related death rates - child poverty. In December I989, in his final speech in Parliament as leader of the New Democratic Party, Ed Broadbent moved a motion that would commit the federal government to end child poverty in Canada by 2000. ${ }^{5}$ The motion was adopted by all, including then Prime Minister Brian Mulroney. Even with a change in ruling parties, Lloyd Axworthy of the Chrétien government reaffirmed his administration's commitment. ${ }^{6}$ In a report card on child poverty, ${ }^{7}$ however, UNICEF's Innocenti Research Centre ranked Canada igth of the 26 OECD countries and found that little to no progress had been made in 15 years on reducing the rate of child poverty.

It may be a coincidence that Canada's world rankings on child injury and child poverty are so similar. However, if Canada were to make a concerted and ultimately successful effort in reducing child poverty, our standing among OECD nations should improve in future UNICEF report cards. Nevertheless, action specific to childhood injuries needs to be taken on a variety of fronts, from the creation of a federal injury prevention strategy ${ }^{1}$ to enactment of healthy public policies at the local, provincial and federal levels. ${ }^{3}$ Collectively, Canada should strive for nothing less than top marks for all aspects of child health.

\section{Richard Stanwick}

Vancouver Island Health Authority

Victoria, BC

This article has been peer reviewed.

\section{REFERENCES}

I. Birken CS, Parkin PC, To T, et al. Trends in rates of death from unintentional injury among Canadian children in urban areas: influence of socioeconomic status. CMAJ 2006;175(8):867-8.

2. A league table of child deaths by injury in rich nations [Innocenti Report Card no. 2]. Florence: UNICEF Innocenti Research Centre; 200I. Available: www.unicef-icdc.org /publications/pdf/repcard2e.pdf\#search=\%22A\%2oLeague $\% 20$ Table $\% 200 \% \% 20$ Child \%20Deaths\%2oby\%2oInjury\%20in\%20Rich\%20Nations\%22 (accessed 2006 Sept I4).

3. Howard AW. Injury in childhood: a vexingly simple problem [editorial]. CMAJ 2006;175(8):899-900.

4. Canadian Paediatric Society. Are we doing enough? A status report on Canadian public policy and child and youth health. Ottawa: Canadian Paediatric Society;2005. Available: www.cps.ca/english/proadv/Advocacy/Status_Report.pdf\#search= \%22Are\%2oWe\%20Doing\%20Enough\%3F\%20A\%20status\%2oreport\%20on\%20 Canadian\%2opublic\%2opolicy\%20and\%20child\%2oand\%2oyouth\%2ohealth\%22 (accessed 2006 Sept I3).

5. Hansard. House of Commons Debates. Available: http://parliı.parl.gc.ca 136/I/parlbus/chambus/house/debates/I79_I999-02-II/hanI79_I6ro-e.htm (accessed 2006 Sept I3).

6. Hansard. House of Commons Debates. Available: http://parlir.parl.gc.ca/35/I /parlbus/chambus/house/debates/o99_94-09-28/099OQIE.html (accessed 2006 Sept I3).

7. Child poverty in rich countries, 2005 [Innocenti Report Card no. 6]. Florence: UNICEF Innocenti Research Centre; 2005. Available: www.unicef.org/brazil |repcard6e.pdf\#search=\%22Child\%2oPoverty $\% 2$ oin $\% 20$ Rich $\% 20$ Countries $\% 20$ 2005.\%22 (accessed 2006 Sept I3). 